SJ Quinney College of Law, University of Utah Utah Law Digital Commons

Utah Law Faculty Scholarship

Utah Law Scholarship

$4-2018$

\title{
Inciting Terrorism on the Internet: The Limits of Tolerating Intolerance
}

Amos N. Guiora

S.J. Quinney College of Law, University of Utah

Follow this and additional works at: https://dc.law.utah.edu/scholarship

Part of the First Amendment Commons

\section{Recommended Citation}

Guiora, Amos N., Inciting Terrorism on the Internet: The Limits of Tolerating Intolerance in Incitement to Terrorism (A. Bayefsky \& L. Blank, eds, Brill 2018).

This Article is brought to you for free and open access by the Utah Law Scholarship at Utah Law Digital Commons. It has been accepted for inclusion in Utah Law Faculty Scholarship by an authorized administrator of Utah Law Digital Commons. For more information, please contact 


\title{
Inciting Terrorism on the Internet: The Limits of Tolerating Intolerance
}

\author{
Amos Guiora
}

\section{Introduction}

The Internet is a limitless platform for information and data sharing. It is, in addition, however, a low-cost, high-speed dissemination mechanism that facilitates the spreading of hate speech, including violent and virtual threats. Indictment and prosecution for social media posts that transgress from opinion to incitable hate speech are appropriate in limited circumstances. Several real-world examples discussed here help to explore when limitations on Internet-based hate speech are appropriate.

In October 2015, twenty thousand Israelis joined a civil lawsuit filed against Facebook in the Supreme Court for the State of New York. Led by the civil rights organization Shurat HaDin, the suit alleges Facebook allows Palestinian extremists to openly recruit and train terrorists to plan violent attacks calling for the murder of Israeli Jews through their Facebook pages. ${ }^{1}$

The suit raises important questions, including: When should the government initiate similar suits to impose criminal sanctions for targeted hate speech posted to Facebook? What constitute effective restrictions on social media that also balance society's need for robust dialogue and free communication, subject to limitations reflecting a need for order and respect among people?

There is a lack of resolution in the ongoing free speech discussion, particularly as it relates to social media. This is quickly becoming a critical focal point given the range, power and impact of the Internet. Social media is how and where contentious public issues are played out. Sometimes, the tone is ugly; numerous examples abound of posts that are racist, hurtful, and deeply insulting. Civil discourse is rare; anonymity enables hatred and calls for violence and harm to others, whether individuals or groups.

The essence of democracy is guaranteeing - and protecting - civil and political rights. Foremost among these rights is freedom of speech. Liberal, democratic governments recognize the right to free speech. The First Amendment of the U.S. Constitution guarantees the right to free speech. International conventions such as the International Covenant on Civil and Political Rights (ICCPR) similarly recognize it. ${ }^{2}$

Free speech is essential for vibrant, robust and rigorous debate, disagreement and contention. It reflects a healthy society, facilitating differences of opinion while respecting tolerance of diversity and creativity. Speech can make us uncomfortable, challenge us, and push us out of our comfort zones.

\footnotetext{
${ }^{1}$ Why 20,000 Israelis are Suing Facebook Over Palestinian Attacks, PBS (Nov. 24, 2016), http://www.pbs.org/newshour/bb/why-20000-israelis-are-suing-facebook-over-palestinian-attacks/.

${ }^{2}$ U.S. Const. Amend. I, International Covenant on Civil and Political Rights, UnITED NATIONS, http://www.ohchr.org/en/professionalinterest/pages/ccpr.aspx/.
} 
The right to free speech is not unlimited. The right is not sacrosanct. Democracies recognize that certain limits may - if not, must - be placed on these rights. U.S. law and jurisprudence recognize a difference between protected speech and unprotected speech, as discussed below.

The relationship between extremism, tolerance, and free speech is complex. Extremism in speech is not a new phenomenon; any effort to limit its scope and impact must be done with sensitivity and respect for otherwise guaranteed rights. However, extremist hate speech confronting - if not challenging - contemporary society is exacerbated both by the tone of the current political climate and the power, speed, and reach of the Internet.

Social networks facilitated by Facebook, Twitter, Google, and YouTube dramatically impact how the message of extremism is conveyed. One of the great challenges confronting democratic decision makers is responding to the Internet's facilitation of extremism while respecting individual and civil rights.

In other words, the challenge is to determine what degree of extremist Internet speech can be tolerated - in the context of freedom of speech - before determining that extremist speech poses a clear and present danger. Balancing is fraught with danger; the consequences of unjustified limitations of free speech are antithetical to a democracy. On the other hand, speech has the potential of harming. The adage "words kill" is neither amorphous nor abstract.

\section{Limiting Internet Speech}

The free speech analysis requires a determination whether the proposed restriction is contentbased or content-neutral. The former refers to restrictions that apply to particular viewpoints, thereby suggesting the proposed restriction carries a heavy presumption that it violates the First Amendment. ${ }^{3}$

When addressing viewpoint-based restrictions, the Supreme Court applies the most stringent standard of judicial review, known as strict scrutiny, in evaluating its lawfulness. To survive strict scrutiny, the restriction must be necessary to achieve a compelling government purpose. ${ }^{4}$ That means that it cannot be, among other things, over-inclusive, under-inclusive, or vague. This standard effectively places a heavy burden on the government to defend the restriction.

However, if the restriction is content-neutral, meaning that the concern is not with the speech itself but rather pertains to the details surrounding the speech, then the government is allowed to set certain parameters involving time, place, and manner. ${ }^{5}$ Content-neutral restrictions on speech are reviewed under intermediate scrutiny rather than strict scrutiny because the speech is restricted solely in the manner in which the information is communicated rather than content itself.

In United States v. O'Brien, the Supreme Court established a four-part test to determine whether a content-neutral restriction on speech is constitutional: (1) Is the restriction within the

\footnotetext{
${ }^{3}$ Burson v. Freeman, 504 U.S. 191 (1992).

${ }^{4}$ Adarand Constructors, Inc. v. Pena, 515 U.S. 200 (1995).

${ }^{5}$ Watchtower Bible \& Tract Soc'y of N.Y., Inc. v. Vill. of Stratton, 536 U.S. 150, 175 (2002).
} 
constitutional power of government, (2) Does the restriction further an important or substantial governmental interest, (3) Is the governmental interest unrelated to the suppression of free expression, (4) Is the restriction narrowly tailored, meaning no greater than necessary. ${ }^{6}$

Subsequently, a fifth factor was added in City of Ladue v. Gilleo, inquiring whether the restriction leaves open ample opportunities of communication. ${ }^{7}$ Finally, there is an exception to the content-based rule that requires an analysis of the value of the speech in question. Certain forms of speech, such as political speech, are thought to be at the very core of the First Amendment's protection, and therefore merit the greatest protection under the law. ${ }^{8}$ The $O{ }^{\prime}$ Brien framework thus helps to establish a framework for how discriminatory, intimidating, disapproving, antagonistic, or prejudicial attitudes expressed towards a disliked target group should be limited within the context of social media.

There are no "safe spaces" on the Internet. To engage on the Internet is to join a fray, oftentimes contentious, and sometimes violent in its language. Although the First Amendment protects vile and odious speech, balancing the free speech interests of the speaker with the content of the chosen platform, safety, and privacy concerns continue to present an ongoing struggle in the Internet age.

The harm is hate speech on the Internet; speech that is distinct from offensive speech. The former must be limited; the latter, regardless of the discomfort it may cause, must be tolerated. The question, based on case law, is how to resolve the limit-tolerate dilemma. That is, the discussion must go beyond the "moral and social responsibility" and articulate legal contours.

The following standard is proposed for determining whether speech morphs into social media hate speech that can be limited: Social media speech cannot be limited through imposition of a bright line rule or an exacting formula. Postings must be assessed on a sliding scale taking into account multiple factors including magnitude, frequency, intent of the platform, and content of the post and platform. ${ }^{9}$ The proposal is based on a suggested Internet-based re-articulation of the Brandenburg test. This recommendation minimizes government excess as it reflects sensitivity to the distinct nature of social media speech while simultaneously recognizing the harm posed by hate speech on the Internet.

Internet speech is different from traditional speech; that difference is particularly important because the future of social media remains unknown, and it would be erroneous to establish a bright line rule articulating when Internet speech should be limited. One of the dangers of an approach that does not tolerate flexibility is enforcement. It is counterproductive to dictate prosecution in accordance with a rule devoid of nuance and flexibility. It is, however, productive to recognize that the Internet's inherent fluidity and unique nature lends itself to a case-by-case approach to determine when limits need be imposed. Attempting to articulate a bright line rule

\footnotetext{
${ }^{6}$ United States v. O'Brien, 391 U.S. 367, 382 (1968).

${ }^{7}$ City of Ladue v. Gilleo, 512 U.S. 43 (1994).

${ }^{8}$ See generally Buckley v. Valeo, 424 U.S. 1 (1976).

${ }^{9}$ Contributed by Jonathan Vick, Assistant Director, Cyberhate Response, Anti-Defamation League. Mr. Vick's substantive contribution of pivotal factors to assess when limiting speech are described below.
} 
— given the nature of Internet speech as analyzed by Cohen-Almagor ${ }^{10}$ — invites government excess when not warranted.

\section{Learning from the Rabin Assassination}

Those who lived in Israel prior to the assassination of Prime Minister Yitzhak Rabin well recall the incessant, consistent and loud incitement articulated by rabbis and others. The unceasing nature of the hate speech directed at Rabin directly contributed to Yigal Amir's decision to assassinate Rabin. That is relevant for our purposes for it highlights - tragically — the consequences of unlimited, unrestrained, and unremitted speech.

Recurring threats are different from single occurrence threats that may not have the same inciting impact. It is for that reason that the proposal above is particularly focused on repetitive speech that suggests a pattern that is more likely to pose harm. Such a limiting paradigm is more aligned with a suitable method for applying Brandenburg to social media. While a one-time viable threat may also be limited; however, the threats that pose the greatest danger are those articulated consistently over time.

With consistency, the magnitude of the threat becomes more realistic, directly corresponding to increased frequency. Accordingly, patterns of hate speech stated on a regular basis warrant special attention and are one factor that must be assessed when determining if speech should be limited.

The context or venue in which Internet speech takes place is perhaps the most pivotal factor in assessing whether speech need be limited. Certain websites intentionally make their forum platform a safe haven for discriminatory hate speech. ${ }^{11}$ These forums serve as a closed community in which like-minded individuals share hate speech posts that support their cause. A webpage dedicated to sharing views in an online forum has less far-reaching implication than posting similar hate speech on immediately disseminated social media pages like Twitter and Facebook. The latter social media platforms disseminate information almost instantaneously to a vast audience and inevitably have the impact to marginalize those targeted by the speech. Accordingly, the context of the chosen platform is directly linked to the far-reaching intent and magnitude of the speech.

Speech must be handled with sensitivity, intelligence, and honesty. Thus, in conjunction with Brandenburg, ${ }^{12}$ it is appropriate to apply J.S. Mill's principle: when it is reasonable and feasible to assume that an act (of speech in that case) will cause harm to others, we should prevent it. ${ }^{13}$ If it is unclear whether speech will result in harm, that speech must be protected; otherwise overreach is the inevitable and problematic result. These joint principles reinforce a case-by-case approach to determine appropriate limitations to Internet speech.

10

11 See for example, Stormfront.org, a neo-Nazi forum that predates the Internet, and is run by a former Klu Klux Klan Grand Dragon, David Duke. The White Supremacist group makes its online home at the stormfront.org website.

12

${ }^{13}$ Anonymous. Private e-mail exchange conditioned on guarantee of anonymity, records in authors' papers. 


\section{Exploration of Real World Examples}

The transnational impact of social media is particularly pertinent when exploring the extent to which government should be allowed to limit Internet speech. Some democratic countries have legislated in the area of state responsibility, but the effectiveness of such legislation is potentially limited by national boundaries, absent the cooperation of other countries. ${ }^{14}$ The essence of the problem is the legal difficulty democratic societies experience in addressing the problem of hate speech on the Internet. The argument of responsibility and the call for a sense of responsibility is compelling. It must, nevertheless, be buttressed by limits established by law that include enforcement mechanisms and punishment. Such limitations are necessary to combat hate speech posing danger to individuals and society alike.

In the U.S., the content-neutrality principle in the application of the First Amendment severely constrains government's ability to deal with the problem. ${ }^{15}$ This is, then, a disturbing weakness that highlights the limits with which governments can counter - much less minimize - hate speech on the Internet. For example, Facebook's claim to be a content-free platform of communication is likely legally defensible, even though practically illogical. ${ }^{16}$ The narrow instance in which the government's ability to limit violent hate speech occurs when there is $a$ targeted and specific threat to an individual person or group.

Although speech cannot be limited with a bright line rule, a substantial number of factors contribute to when speech could be limited. The principle articulated above is a useful starting point - when it is reasonable and feasible to assume that an act of Internet speech will cause harm to others, we should prevent it. ${ }^{17}$ Targeted hate speech that carries with it immediate harm (capability to carry out the violence), individualized harm (capability to assault the target), and capability to carry out the threat (actualized means of committing the violence), must be limited.

The public has been confronted with a number of significant free speech issues in the past few years; this essay examines four real world examples. In analyzing these examples, the point of inquiry is whether the test articulated by the Supreme Court in Brandenburg when applied to Internet speech sufficiently protects the speaker, the audience, the larger public and the intended target of the speech. Only one example below highlights the narrow instance where limitation of Internet speech would be appropriate.

\section{A. Ted Nugent's Anti-Semitic National Rifle Association Posting}

Ted Nugent's February 8, 2016 Facebook post features Israeli flags on a collage of the faces of prominent Jewish Americans with the text, "So who is really behind gun control?" Mr. Nugent's controversial and anti-Semitic messages drew national news coverage and criticism of $\mathrm{Mr}$.

\footnotetext{
${ }^{14}$ See generally id. at 230 (discussion on State Responsibility); see, e.g., Yahoo! Inc. v. La Ligue Contre Le Racisme et L'Antisemitisme, 169 F.2d 1181 (N.D.Cal. 2001), rev'd., 433 F. 3d 1199 (9 ${ }^{\text {th }}$ Cir.), cert. den. 547 U.S. 1163 (2006)..

${ }^{15}$ See for example., R.A.V. v. City of St. Paul, 505 U.S. 377 (1992).

${ }^{16}$ Cited contributor is anonymous.

${ }^{17}$ Anonymous. Private e-mail exchange conditioned on guarantee of anonymity, records in authors' papers.
} 
Nugent, an outspoken advocate of gun-rights and the Second Amendment. The anti-Semitic graphic received praise by some groups, condemnation by others, and started an active online debate.

The Anti-Defamation League (ADL), founded in 1913 "to stop the defamation of the Jewish people and to secure justice and fair treatment to all," called for removal of Nugent's post. ${ }^{18}$ ADL is a premier civil rights agency that fights anti-Semitism and all forms of bigotry, defends democratic ideals and protects civil rights for all. ${ }^{19}$ Although it is legitimate for the ADL, and other private actors generally,to call for removal of controversial viewpoints and build popular pressure to cause the NRA to distance itself publicly from Nugent's views, the same cannot be said for a government body mandating limitation of the speech. ${ }^{20}$ This is not an instance in which the government could limit Internet speech. As vile, anti-Semitic, or odious Mr. Nugent's posting may be, it need not be removed from social media.

\section{B. Inflammatory Sam Houston State University Student Tweet}

Consider the following September 2015 Twitter posting ("tweet") by Sam Houston State University ("SHSU") student Monica Foy. Her post was connected to the death of Harris County, Texas Sheriff's Deputy Darren Goforth, who was killed August 28, 2015 while pumping gas into his police car.

Ms. Foy tweeted, "I can't believe so many people care about a dead cop and NO ONE has thought to ask what he did to deserve it. He had creepy perv eyes . .."21

Multiple news sources picked up the tweet and the ensuing backlash caused the tweet to go viral, despite Ms. Foy deleting it. Ms. Foy received threats, later issued an apology, and was also arrested on an outstanding warrant for a previous assault charge.

SHSU responded shortly after Ms. Foy's initial tweet, issuing the following statement: "SHSU has a strong Student Code of Conduct. The student's remarks will be evaluated to determine if the code was violated following standardized due process. The university has an ongoing commitment to taking actions that strengthen dialog and understanding between our students and the law enforcement community." 22 This response provoked additional controversy; SHSU was criticized for both contemplating limiting Ms. Foy's First Amendment rights and for not taking more aggressive action to limit the distasteful speech. The criticism highlighted the complexity of the free speech discussion — while some would argue Ms. Foy's post typified the "dark

\footnotetext{
${ }^{18}$ About the Anti-Defamation League, ADL, http://www.adl.org/about-adl/.

${ }^{19}$ Id.

${ }^{20}$ For example, Oberlin College in Ohio was recently at the center of a social media controversy regarding Facebook postings made by one of its professors, Joy Karega. Karega posted a number of anti-Semitic statements on her Facebook page. Oberlin College is a private actor and the issue is not a question in which the government may intervene.

${ }^{21}$ Apologetic Sam Houston State Student Won't Get Punished by Sam for Tweet, KBTX http:/www.kbtx.com/home/headlines/Apologetic-Sam-Houston-State-Student-Wont-Get-Punished-by-Sam-forTweet-324742191.html.

${ }^{22} I d$.
} 
side" ${ }^{, 23}$ Cohen-Almagor notes, others would suggest the post articulated a legitimate position in the context of an important public discussion regarding the relationship between law enforcement and the public. That discussion, as uncomfortable and controversial as it may be, is "front and center" in America and to that end, posts — even if "edgy" — need not be limited.

SHSU President Dana Hoyt issued a statement after "much time" examining the "careless remarks" of Ms. Foy; President Hoyt clarified Ms. Foy would not be punished for her remarks. ${ }^{24}$ Hoyt stated, "A personal comment made on a private social media account, as offensive as it was, remains protected by the First Amendment. Offensive speech is still protected speech.",25 Hoyt went on to state, "Ms. Foy has issued an apology and will have to live with the consequences of her actions ... Our response maintains both our academic integrity and upholds the Constitution of the United States of America. Sometimes the right choice is not always the most popular decision." 26 In this instance, SHSU correctly determined Ms. Foy's speech can be considered offensive by some, but is ultimately harmless, and therefore should not be limited.

\section{Palestinian Terrorist Facebook Posts Encouraging Vehicle Run Over Attacks}

In late 2015, numerous Palestinian terrorist groups posted messages on social media encouraging Palestinians to commit car-ramming attacks intended to run over Jews. For example, on November 12, 2015, one Facebook post read, "Today Wednesday is the day of Run over against Zionists. Get ready for a case of Run over. I pray it will be a case of Run over that will terminate a large number of Zionists." 27 Another posting included an image and text that read, "Its true gas is expensive but Jews are cheaper, \# Run over oh you great [person]." ${ }^{28}$ The photo shows Israeli victims of a run-over terror attack dead in the streets of Israel with an Arabic text photo-shopped on the picture reading "Accelerate." 29

There are colorable arguments on both sides of the issue of whether these postings should be restricted. In the context of Professor Cohen-Almagor's argument regarding "social and moral responsibility,"30 it appears that the postings violated standards of responsibility, however, it would be inappropriate to limit the free speech of the posters in accordance with Brandenburg. Unlike the posting with specific instructions on how to stab a Jew to death discussed below, this posting is more general and therefore less clear in its "how to" instructions. Although there is little doubt as to the intent of the posting and the fact that Palestinians did indeed commit "car ramming" terrorist attacks, limiting the post would be an overreaching attempt to limit free speech. The recommendation not to do so reflects a legal argument positing that the speakers do not pose a threat both to specific individuals and larger society. The irresponsibility, and lack of moral and social responsibility of the posters does not justify imposition of legal restrictions. 
The counter-argument to this conclusion is that the speaker can inflict immediate harm by operating a motor vehicle (capability to carry out the violence), the harm is individualized (capability to assault the target walking down the street), and the capability to carry out the threat is readily accessible (actualized means of committing the violence with their car is realistic). Nevertheless, this generalized posting is not an instance that warrants limitation.

\section{Palestinian Terrorist Facebook Stabbing Attack Posts}

As briefly noted in the introduction, in October and November 2015, Palestinian terrorists issued a widespread call for stabbing attacks against Jewish citizens living in Israel. Consequently, in October 2015, twenty thousand Israelis joined a civil lawsuit filed in the Supreme Court for the State of New York by Shurat HaDin, an Israeli civil rights organization, against Facebook. The suit alleged that Facebook allowed Palestinian extremists to openly recruit and train terrorists to conduct violent attacks against Israeli Jews.

An Israeli Ministry of Foreign Affairs official slammed Facebook and YouTube for rejecting repeated requests to automatically intercept content that could lead to assaults against Jews. ${ }^{31}$ The official stressed the problematic nature both of recruitment on Facebook of many young people by radical Islamist groups and of "lone-wolf" Palestinian terrorists incited to kill Jews in Israel. Additional Facebook postings with graphic images were posted in the following months. One image included text that read, "If we won't pull the trigger then we will put our foot to the gas and stab with the knife." 32 Subsequently, a Facebook image and accompanying video purported to teach would-be Palestinian attackers "how to stab" Jews. ${ }^{33}$ Detailed and violent photos posted to social media include step-by-step instructions for maximizing bodily damage against Jews.

This is a narrow instance where speech should be limited. The speech is targeted hate speech that carries with it each of the aforementioned criteria for limiting speech: immediate harm (capability to carry out the violence on identifiable target with growing momentum of attacks), individualized harm (capability to assault the target/neighbor/individual walking down the street), and capability to carry out the threat (actualized means of committing the violence with a common knife).

\section{Conclusion}

Swastikas spray-painted on the door of a Colorado elementary school and on several college campuses. $^{34}$ A rally for the President-elect of the United States featuring a "Heil Hitler" salute. ${ }^{35}$ A proposed registry for Muslims leading to unease and fear across communities. ${ }^{36}$

\footnotetext{
${ }_{32}^{31} \mathrm{http}: / / w w w . n r g . c o . i 1 /$ online/1/ART2/754/848.html?hp=1\&cat=404\&loc $=68$.

${ }^{33} I d$. 
Benjamin Kuperman, a professor at Oberlin College, awoke to sounds of tapping outside his home to find a note behind his mezuzah (a small case that contains verses from the Torah, common for Jews to place on their door frames) that stated, "Gas Jews Die." ${ }^{, 37}$ A similar scenario unfolded at Harvard University, where a professor recently received a postcard stating, "Juden raus!"38 a phrase introduced by the Nazis that translates to mean "Jews out."

Take out the location and time stamp on the aforementioned examples and it is easy to see why many are comparing the rise of the alt-right in the U.S. to Nazi Germany decades ago. To some, these incidents are clear-cut examples of hate speech. To others, expressing the viewpoint of the so-called white nationalist movement is a First Amendment right that should be allowed - and celebrated - as free speech without censorship.

The growing division between these schools of thought brings up a simple question with a complicated answer: How much intolerance should be tolerated?

Some may argue the issue was settled long ago in Brandenburg v. Ohio, the landmark U.S. Supreme Court ruling from 1969 when the Court reversed the conviction of a Ku Klux Klan leader who had advocated violence. Clarence Brandenburg was charged and convicted for advocating violence under Ohio's criminal syndicalism statute in 1964 for speeches he made.

At one rally, he stated "Personally, I believe the n----- should be returned to Africa, the Jew returned to Israel." He also commented - as several Klan members stood by with firearms "We're not a revengent organization, but if our President, our Congress, our Supreme Court, continues to suppress the white, Caucasian race, it's possible that there might have to be some revengeance taken.”

Brandenburg appealed his conviction to the U.S. Supreme Court, claiming Ohio's statute violated his First Amendment rights under the U.S. Constitution. The court sided with him, issuing what is still considered today to be its most speech-protective holding. The ruling created a litmus test citing three factors when speech can be prohibited: 1) if the speech promotes imminent harm, 2) there is a high likelihood the speech will result in listeners participating in illegal action and 3) the speaker intended to incite others to participate in illegality. ${ }^{39}$

The task of drawing the line in determining when speech incites others to behave is enormously complex.

The 1969 ruling came well before the digital age. We live in a time where clicks and shares spread hate and false information instantaneously across the Internet.

Given the tone and tenor in society following the election of Donald Trump, I believe it is time to revisit limits on free speech. 
The challenge is to determine what degree of extremist Internet speech can be tolerated - in the context of freedom of speech - before determining that extremist speech poses a clear and present danger. Balancing is essential; the consequences of unjustified limitations of free speech are antithetical to a democracy. On the other hand, speech has the potential for harming. The adage "words kill" is neither amorphous nor abstract.

Speech must be handled with sensitivity, intelligence, and honesty. When reasonable to assume speech will cause harm to others, we should prevent it. If unclear whether speech will result in harm, it must be protected; otherwise overreach is the inevitable and problematic result.

Brandenburg must be understood to not only protect the speaker's rights, but to also ensure protection of potential targets. As has been made dramatically clear in the past weeks there is potential danger to minority groups. They are deserving of our protection. We are living in a time when reports of hate are surfacing at an alarming rate.

The First Amendment limitations primarily address the government-citizen axis of speech constraint. Social media companies like Facebook and Twitter are private enterprises, and accordingly fall on the citizen-citizen axis. ${ }^{40}$ It is for that reason that adoption of legal limits on free speech in social media is essential. In proposing establishment of legal limits on social media, the primary concern is balancing victim and speaker rights. Needless to say, the implications of recommending the imposition of restrictions on free speech in the social media age are problematic and troublesome.

In narrow circumstances, the duty to legally protect victims of hate speech outweighs the privilege of freedom of speech otherwise granted to those who engage in social media.

\footnotetext{
${ }^{40}$ See Citizens United v. Federal Election Commission, 558 U.S. 310 (2010).
} 